\title{
Analysis Of Stress Distribution Connection System To Knock Down River Ferry
}

\author{
,Edi Jadmiko ${ }^{1}$, Irfan Syarif Arief ${ }^{2}$ Cahyo Putro Indro Suseno ${ }^{3}$
}

\begin{abstract}
Musi river is a wide and very long river used by local citizen for the fro. Water transportation remains the choice of local citizen though other infrastructure was built. Hence today, water transportation remains best choice because it has better time compared to landline. This research aims to get simple solution which is quite good, effective, and quick when needed, then author made Knock Down River Ferry design. Knock Down River Ferry consists of certain size pontoon. Of course this ferry have advantages in moving and assembling. This pontoon can easly assembled in few day and various river width. In this Research there is problem identification and formulation about pontoon joints design of the ferry so force can distributed evenly when receive load.. The analysis process obtained the strength of the lock with the variety conditions of the ships, the largest stress lies on the lock number 10 on the ship moving conditions with a speed of 8 knots for 31.85 MPa with safety factor 8.635 and the lowest on the lock number 1 on the floating condition with stress for $0.91 \mathrm{MPa}$
\end{abstract}

\section{Keywords—Pontoon, Knock Down, Load Distribution, Connection System, River Ferry}

\section{INTRODUCTION}

Musi river located in South Sumatra. This river has a length of $750 \mathrm{~km}$, an average width of $540 \mathrm{~m}$ ( the longest $1350 \mathrm{~m}$ ) located around Kamaro Island (shortest width $250 \mathrm{~m}$ ) and a depth 15-20 m. Musi river has two islands namely Kembaro and Kerto. The other three major rivers are the Komering River with average width of $236 \mathrm{~m}$, Ogan river with an average width $211 \mathrm{~m}$, and Keramasan river with an average width $103 \mathrm{~m}$, This river is the longest river in Sumatra and split the city of Palembang into two parts. The water transportation centre in Palembang is located at the pier of Plaza Benteng Kuto Besak (BKB), precisely under the Ampera Bridge.

A wide and elongated river is very fitting to be a mainstay of residents transportation. The water transportation remains first choice of local residents despite various modern infrastructures built in South Sumatra. Travel to OKI (Ogan Komering Ilir) can be reached by land route about 5-6 hours. Therefore, until now the river transportation remains the best option because it only has time about 1-2 hours.

Because build a bridge will take aa lot of time and very costly , a simple solution and effective as well as fast when needed. Knock Down River Ferry is the solution for the problem. Knock Down River Ferry is a ship that can be dismantled pairs according to the state of the river to be skipped and can be transported section, and easyli assembled on site within a few days. Intended to transport trucks or either vehicles that are in empty or full of cargo. Loading and unloading of cargo can be done anywhere and has a shallow draft making it easyer to land and does not require large port.

In this final project, will be design a Knock Down River Ferry by analizing the ship connection with the force distribution that occurred.

\section{METHOD}

Identification and formulation of the problem of how to

Edi Jadmiko with Departement of Marine Engineering, Sepuluh Nopember Institute Of Technology ,Surabaya 60111,Indonesia.

Irfan Syarief Arief with Departement of Marine Engineering, Sepuluh Nopember Institute Of Technology ,Surabaya 60111,Indonesia.

Cahyo Putro Indro Suseno with Departement of Marine Engineering, Sepuluh Nopember Institute Of Technology ,Surabaya 60111,Indonesia. design the knock down connection on the ship, so that distribution of the force can be evenly distributed. The first step is Lines plan Drawing which is described with the aim to know the hull of the ship and the hull characteristic of the ship especially under the water line area, where the drawing is made on the basis of the establishedwater line. The length and width of the ship is obtained from the maximum number of vehicles that planed. After obtaining the hull ship, the vessel is divided per block according to design. From the previous design is designed with a references standard that can accept the load to be received. In the Lines plan design also dwaring all the equipment of the ship, included cargo. Then conducted stress analysis on the ship connection that has been designed with the Solidwork software

\section{RESULTS AND DISCUSSION}

\section{A. Pontoon}

Pontoons are floatimg units that are unmanned or manned with or without self propulsion. The comparison of pontoon principal dimension is different from those common;y used on ships. Pontoon are usually designed as deck load carriers or work equipment and have no hold to carrying cargo.

\section{B. Principal Dimension Planning}

Planning of the principal dimension of this pontoon is based on the main principal of references pontoon.. The comparative pontoon is used as a constraint to determine the minimum and maximum values of the main pontoon principal dimension in addition to the exixting constraint that are the boundary effect of the regional conditions that must be met in accordance with the final references that discusses the optimizing of ship principal dimension on the musi river.

Comparative pontoon data as references can be seen in table 3.1. 
Tabel 3.1 Comparative pontoon main principal

\begin{tabular}{|c|l|c|c|c|c|}
\hline No & Name of Pontoon & $\mathrm{L}$ & B & T & $\mathrm{H}$ \\
\hline 1 & Bengawan Barge & $11.75 \mathrm{~m}$ & $4.00 \mathrm{~m}$ & $0.45 \mathrm{~m}$ & $0.80 \mathrm{~m}$ \\
\hline 2 & River Poonton & $15.0 \mathrm{~m}$ & $6.00 \mathrm{~m}$ & $1.35 \mathrm{~m}$ & $2.40 \mathrm{~m}$ \\
\hline 3 & Flat Top Barge & $25.5 \mathrm{~m}$ & $5.20 \mathrm{~m}$ & $1.10 \mathrm{~m}$ & $1.70 \mathrm{~m}$ \\
\hline 4 & River Barge & $36.6 \mathrm{~m}$ & $6.15 \mathrm{~m}$ & $0.80 \mathrm{~m}$ & $1.53 \mathrm{~m}$ \\
\hline
\end{tabular}

In this optimizization process, the limits used are:

- Maximal Draft (T max) : $9 \mathrm{~m}$, is the maximum draft on this pontoon operation area. This figure is obtained from ship draft that operating in Musi river.

- Minimal Draft ( $\mathrm{T}$ min) :1 $\mathrm{m}$, is the minimum requirement obtained frim the comparative pontoon.

- Makximal Length ( Lpp max) : $100 \mathrm{~m}$, is the pontton length obtained from comparative pontoon.

- Makximal Breadth ( Bmax) : $18 \mathrm{~m}$, is the maximum width obtained from comparative pontoon to match the working area on the Musi river.

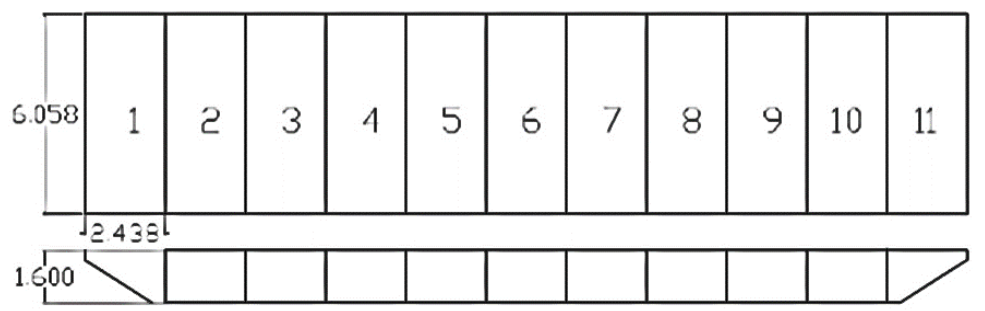

Figure 3.1 Pontoon Design

Then the principal dimension of the pontoon ia adjusted to the limitations of ship optimization in the waters of the river. So the main principal is arranged as follows:

$\begin{array}{ll}\text { LOA } & : 26.818 \mathrm{~m} \\ \mathrm{~B} & : 6.058 \mathrm{~m} \\ \mathrm{~T} & : 1.6 \mathrm{~m} \\ \mathrm{D} & : 1.25 \mathrm{~m}\end{array}$

Calculation of the principal dimension ratio:
$\mathrm{L} / \mathrm{B} \quad: 4.43$
$\rightarrow 3.4<\mathrm{L} / \mathrm{B}<10$
$\mathrm{L} / \mathrm{T}: 20.63$
$\rightarrow 10<\mathrm{L} / \mathrm{T}<30$
B / T : 4.66
$\rightarrow 1.8<\mathrm{B} / \mathrm{T}<5$

Principle of Naval Architecture Vol.1

C. General Arrangement

General arrangement is defined as the planning of the required room in accordance with its function anf equipment and includes the placement of access planning.

a) Lifting and Lashing Point

One of the safety tools on the vehicles to be transported on board, is a locking point on the
- Makximal height $(\mathrm{H})$ : $9 \mathrm{~m}$ obtained from the high consideration of the bridge free pass

In accordance with the mainpurpose of the ship made to be dismantled pairs and facilitate the mobility og shiping or sshifting the vessel size per block will be adjusted to the size of 20 feet container that will connected to reach the main size of the ship. With the initial design as shown in figure 3.1

vessel for binding or webbing on the vehicles to avoid or prevent accidental movement when the vehicles on the ship is hit by shocks from water waves.

b) Wheel Chock

The next safety tool is wheel chock, can be wood or rubber with a certain size that works to avoid the vehicles does not to slip when the vehicle on the ship hit by shocks of water waves, in addition to rely on the hand brake arrangement of the vehicle itself. One edge of the wedge has a concave profile for contour to the wheel thus increasing the required strength

c) Contruction Calculation

The calculation of contruction profile is based on the provisions of BKI ( Biro Klasifikasi Indonesia ) 20016 volume II. Here on the table 4.1 Heavy Construction of vessel in 1 block. 
Tabel 4.1 Weight of 1 block Hull Construction.

\begin{tabular}{|c|c|c|c|c|c|c|}
\hline No & Item & Size & Thicknes (mm) & Quantity & \multicolumn{2}{|c|}{ Weight } \\
\hline 1 & Plate Deck & $14.20 \quad \mathrm{~m}^{2}$ & 8 & 1 & 0.892 & ton \\
\hline 2 & Longitudinal Bulkhead & $3.73 \mathrm{~m}^{2}$ & 8 & 1 & 0.234 & ton \\
\hline 3 & Keel Plate & $2.34 \mathrm{~m}^{2}$ & 10 & 1 & 0.184 & ton \\
\hline 4 & Bottom Plate & $1.52 \mathrm{~m}^{2}$ & 8 & 2 & 0.191 & ton \\
\hline 5 & Side Plate & $2.09 \mathrm{~m}^{2}$ & 7 & 2 & 0.230 & ton \\
\hline 6 & Frame & $1.11 \mathrm{~m}^{2}$ & 12 & 2 & 0.210 & ton \\
\hline 7 & Decks & $0.55 \mathrm{~m}^{2}$ & 10 & 2 & 0.087 & ton \\
\hline 8 & Waterlight Bulkhead & $11.41 \quad \mathrm{~m}^{2}$ & 7 & 2 & 1.254 & ton \\
\hline 9 & Watertight Bulkhead Plate & $9.64 \mathrm{~m}^{2}$ & 7 & 4 & 2.120 & ton \\
\hline 10 & Wrang Bottom Plate & $0.39 \mathrm{~m}^{2}$ & 9 & 6 & 0.165 & ton \\
\hline 11 & Wrang Top Plate & $0.39 \mathrm{~m}^{2}$ & 9 & 8 & 0.220 & ton \\
\hline 12 & Wrang Side Plate & $0.79 \quad \mathrm{~m}^{2}$ & 9 & 8 & 0.445 & ton \\
\hline \multicolumn{5}{|c|}{ TOTAL WEIGHT STEEL } & 6.231 & ton \\
\hline
\end{tabular}

d) Payload

Based on the main principal of the vessel and the description on the maxsurf, the displacement

The amount of weight permitted abbreviated JBI is the maximum weight of the motor vehicle and its cargo is permitted on the basis of the road class. The amount of weight allowed is greater if the number of vehicle axes more and more. Or it can be formulatedJBI $=\mathrm{BK}+\mathrm{G}+\mathrm{L}$, where $\mathrm{BK}$ is was 181.7 tons, while the weight of the ship was 65.79 tons, leaving 116.2 tons.

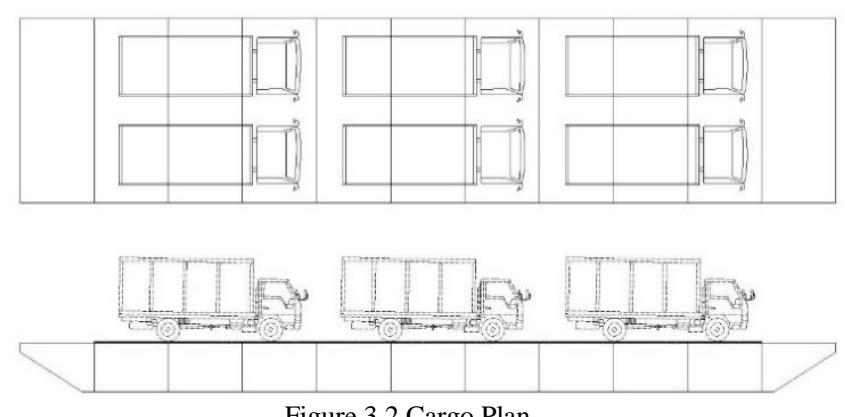

Figure 3.2 Cargo Plan

\section{e) Exle Load}

Exle Load is the amount of wheel pressure from one vwhicle axis to the deck of the ship. The load is then distributed to the hull construction. Distribution of load distribution later as a reference testing to be used with the help of software. empty weight of the vehicle; $G$ is the weight of the persona; $\mathrm{L}$ is the weight of charge.

In the calculation of the deck load taken the size of the large truck weighing 16 tons, with the size of existing ship capacity then the ship can contain 6 large trucks in accordance with figure 3.2

\section{Connection Design}

Planning the correction with reference to standard housing plate modified and adjusted to the load to be received.

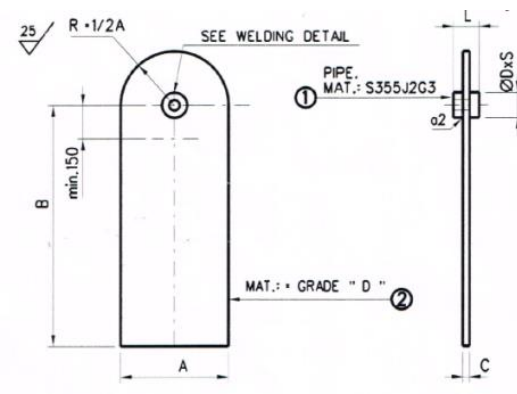

\begin{tabular}{|c|c|c|c|c|c|c|c|c|c|c|c|}
\hline \multirow{2}{*}{$\begin{array}{l}\text { TYPE } \\
\text { NR. }\end{array}$} & \multirow{2}{*}{$\begin{array}{l}\text { WORKWIC } \\
\text { LOAO } \\
\text { N T. }\end{array}$} & \multicolumn{5}{|c|}{ DENSSIONS } & \multirow{2}{*}{$\begin{array}{l}\text { THROAT } \\
\text { OF THE } \\
\text { WELD Q2 }\end{array}$} & \multirow{2}{*}{$\begin{array}{c}\text { MASS } \\
\text { No } \\
\mathrm{kg} / \mathrm{pC} \text {. }\end{array}$} & \multirow{2}{*}{$\begin{array}{l}\text { ART,COOE } \\
\text { POS } 1\end{array}$} & \multirow{2}{*}{$\begin{array}{l}\text { ART,COOE } \\
\text { POS2 }\end{array}$} & \multirow{2}{*}{$\begin{array}{l}\text { ART,COOE } \\
\text { ASSENGLLY }\end{array}$} \\
\hline & & $\bar{A}$ & & C & $\varnothing 0 \times 5$ & L & & & & & \\
\hline $3-17$ & 17 & 190 & 800 & 20 & $108 \times 25$ & 55 & 5 & 27 & 08 & 01 & 644 \\
\hline $3-25$ & 25 & 240 & 800 & 25 & $108 \times 25$ & 62 & 0 & 44 & 8 & 01 & 6 \\
\hline $3 \cdot 35$ & 40 & 320 & 800 & 30 & $159 \times 32$ & 80 & 6 & 76 & 62 & 276 & $6443 / 084$ \\
\hline 3.55 & 55 & 370 & 800 & 30 & $159 \times 32$ & 95 & 8 & 87 & $1423 / 162$ & $2760 / 101$ & $6443 / 085$ \\
\hline & 85 & 480 & 108 & 30 & $159 \times 3$ & 115 & 10 & 15 & & 01 & $6443 / 086$ \\
\hline
\end{tabular}

Figure 3.3 Standard 
With reference to the standard then planned connection to be able to accept the load as needed. Planned construction design as follows

Figure 3.4 Locking Connection Planning
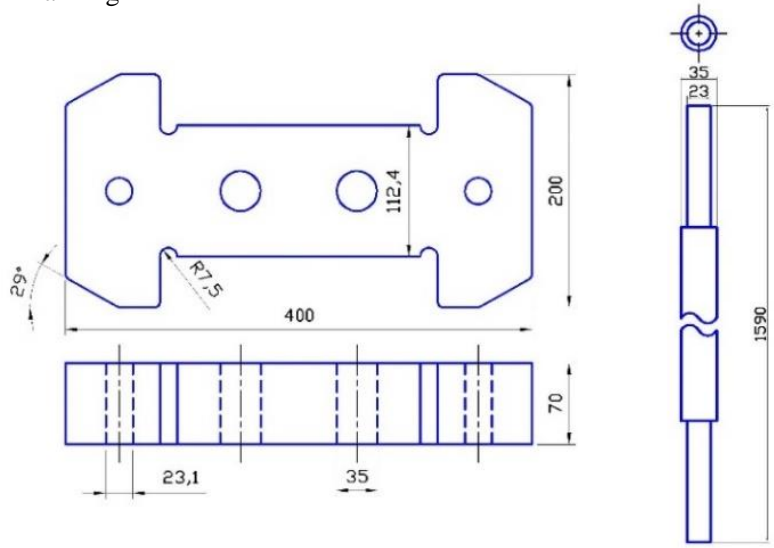

\section{E. Modeling Pontoon}

Result of modeling pontoon that has been in the image pontoon blocks that are blocked from AP,middle block, on software Solidwork 2007. There are 3 different and FP block.

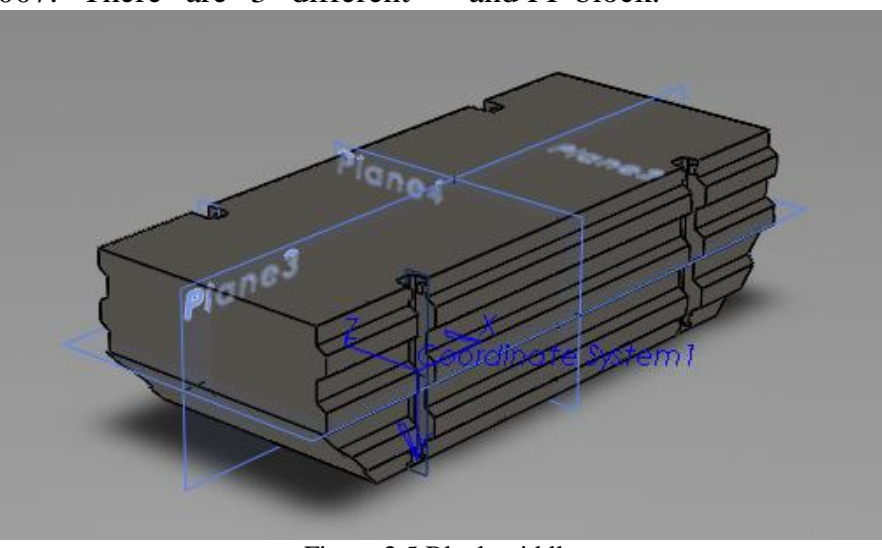

Figure 3.5 Block middle

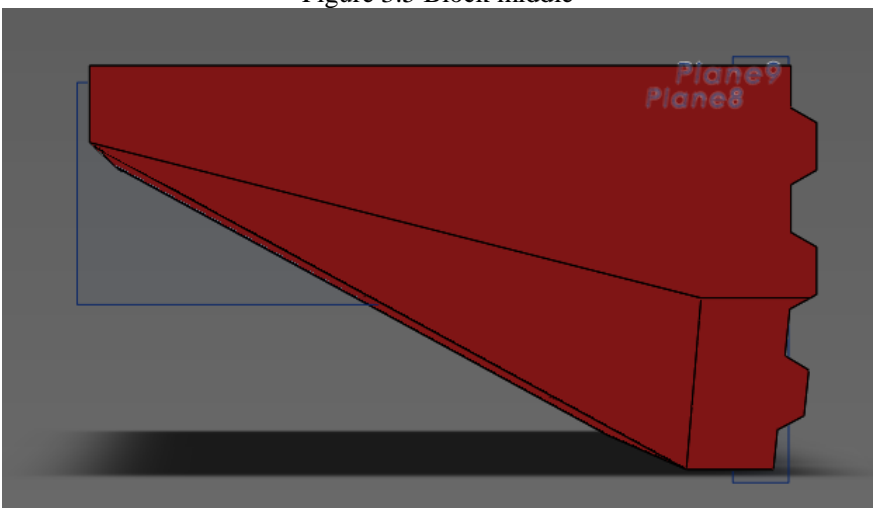

Figure 3.6 Block AP 


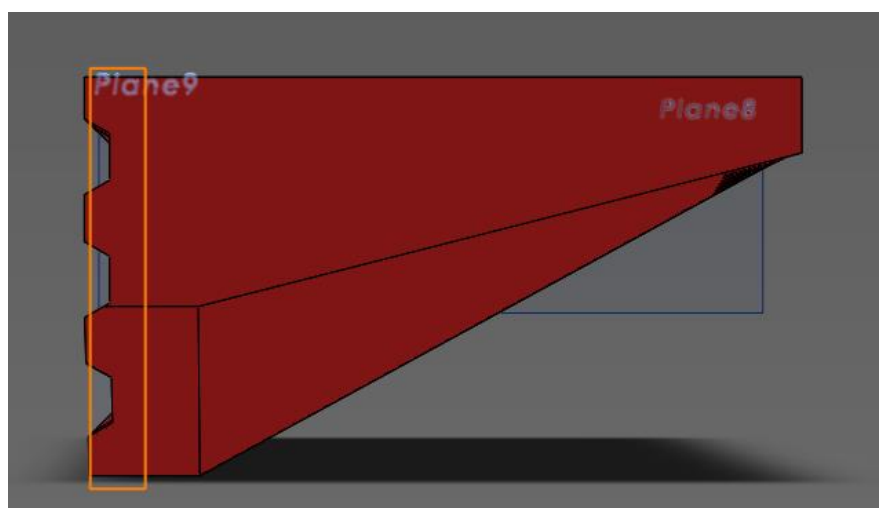

\section{F. Locking Strength Analysis}

Use material data input process, first determine the construction material data that will be used in connection design. Data input material is required to peform strength analysis because it is related to $\mathrm{K}$ factor which then affects the equivalent stress permit, bending stress permit, and safety factor which become the reference of acceptance and rejection criteria. In accordance with previous data hull using materials ship is alumunium alloy 6061. With specifications as follows:

\section{Material - Type}

Density

Yield Strength : Alumunium Alloy 6061

$$
: 2700 \mathrm{~kg} / \mathrm{m}^{3}
$$$$
\text { : } 275 \mathrm{MPa}
$$

Max. Tensile Strength

$$
\text { : } 310 \mathrm{MPa}
$$

The locks are loaded from the bottom, with the help of maxsurf hidromax software can be known by the weight of the previously calculated vessel construction of 65.79 tons plus the weight of the lock with a total weight of $176.8 \mathrm{~kg}$ and the added load of 6 trucks with a total weight of 96 tons then the total entirely in the position of the ship on laden and with a 162.2 displacement volume with 1129 loads.

That it can be determined the press force on the boat with the formula

$$
\begin{aligned}
& \mathrm{F} \quad=V \times g \times \rho \\
& \text { Where: } \\
& \mathrm{F} \quad=\text { Force } \quad(\mathrm{N}) \\
& \mathrm{V} \quad=\text { Volume } \quad\left(\mathrm{m}^{3}\right) \\
& \rho \quad=\text { Density } \quad\left(\mathrm{kg} / \mathrm{m}^{3}\right) \\
& \text { g = Gravity } \quad(\mathrm{N} / \mathrm{kg}) \\
& \text { then : } \\
& \mathrm{F}=144.57 \times 9.8 \times 1.025 \\
& \mathrm{~F} \quad=1452.29 \mathrm{~N}
\end{aligned}
$$

Then the load from the bottom is given as $363.08 \mathrm{~N}$. because of the buoyancy load of the vessel divided by 4 pivot point. With the result of analysis in figure 4.16 and images 3.10 and 3.11 .

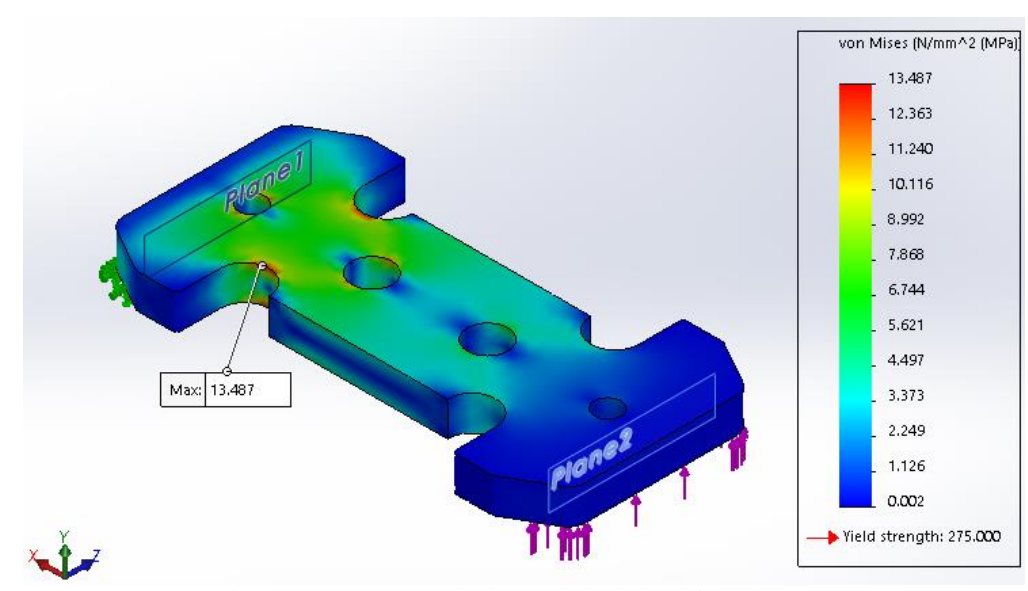

Figure 3.8 Stress analysis result lock load from bottom 


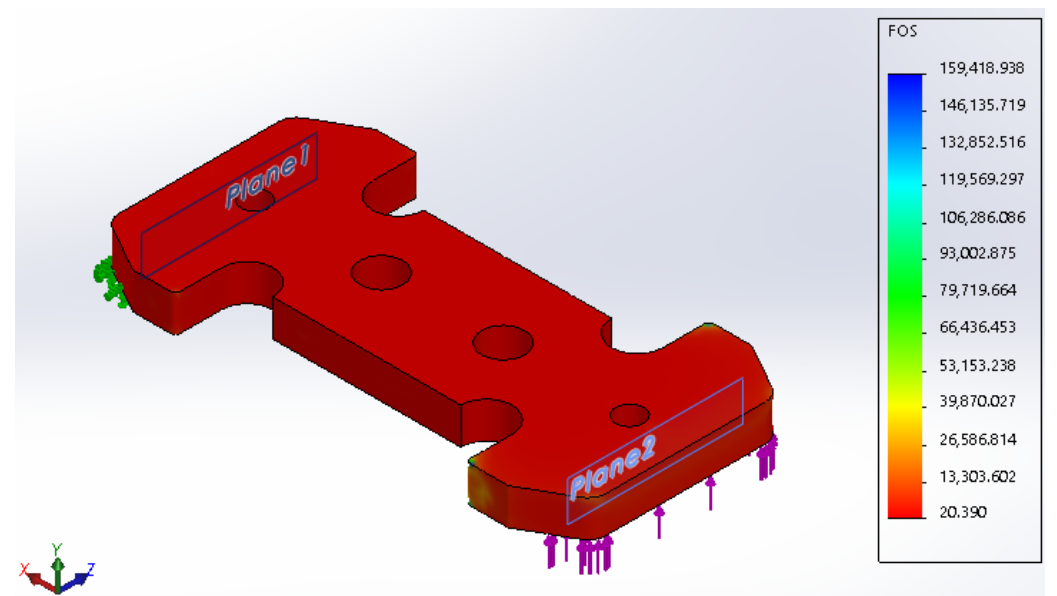

Figure 3.9 Safety factor result load lock from bottom

In subsequent analysis the locks are given the tensile load obtained from the previous planning that is from the ship resistance of $\& .27 \mathrm{kN}$ with a speed of 8 knots. Then the analysis is given a tensile load of $1817.5 \mathrm{~N}$ with the result of analysis in figure 3.10 - figure 3.13.

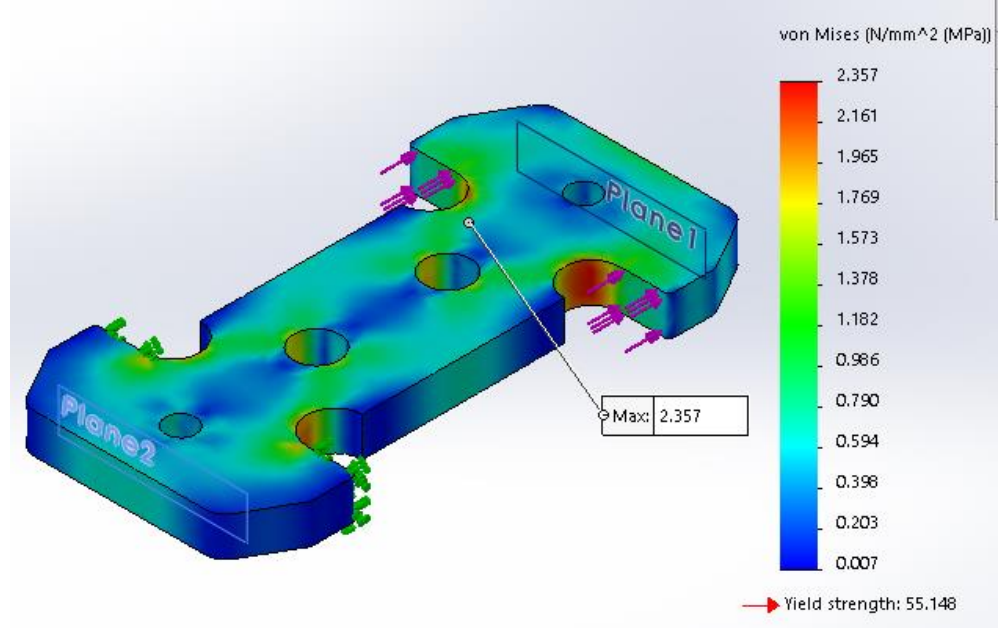

Figure 3.10 Side load Pulling Lock Stress analysis

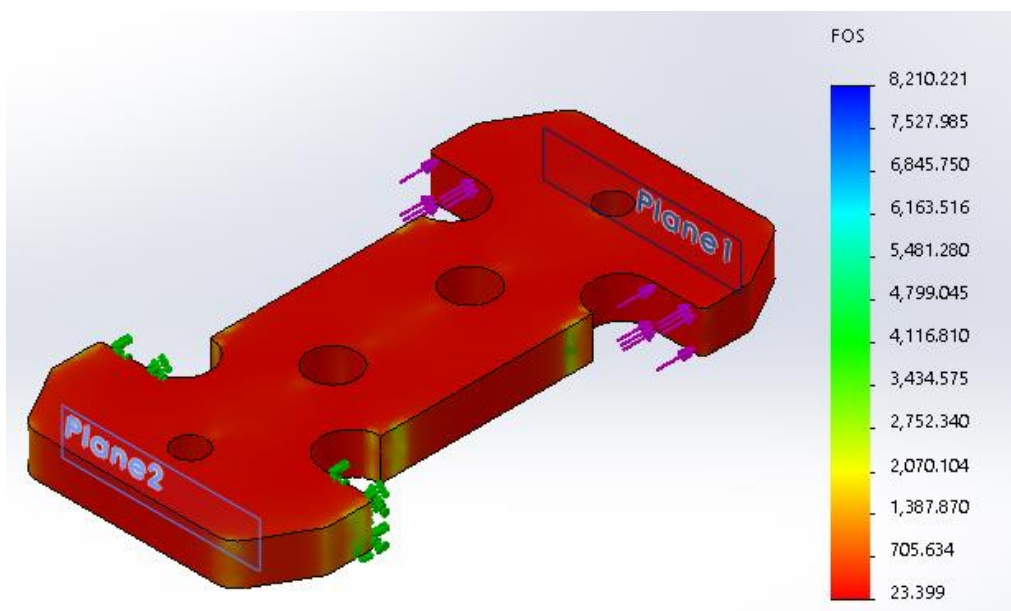

Figure 3.11 Safety Fsctor from Side Lockout Result 
G. Assembly Lock Analysis

In the process of load analysis from below given

divided by 2 piot point. With the result of analysis in $726.14 \mathrm{~N}$ comes from the buoyancy load of the vessel figure 3.14 and figure 3.15 .

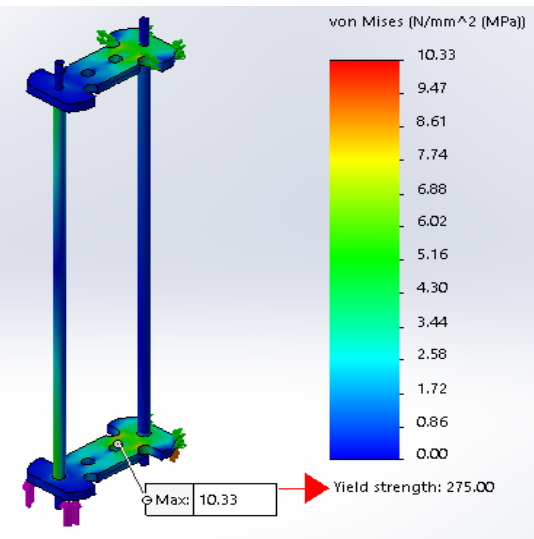

Figure 3.12 Stress Analysis Assembly From Bottom locks

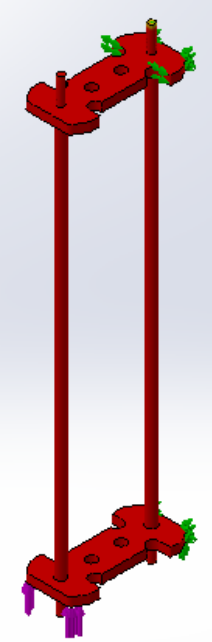

FOS

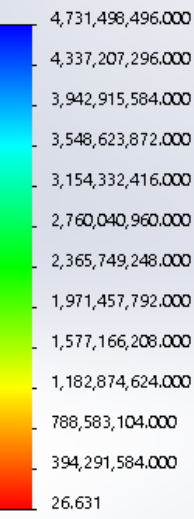

Figure 3.13 Safety Factor Assembly Result From Bottom

Assembly locking given the tensile load obtained from the previous planning of the ship with a velocity of 8 knots of $7.27 \mathrm{kN}$. Then the analysis is given a tensile load of $3635 \mathrm{~N}$ with the result of analysis in figure 3.14 and 3.17

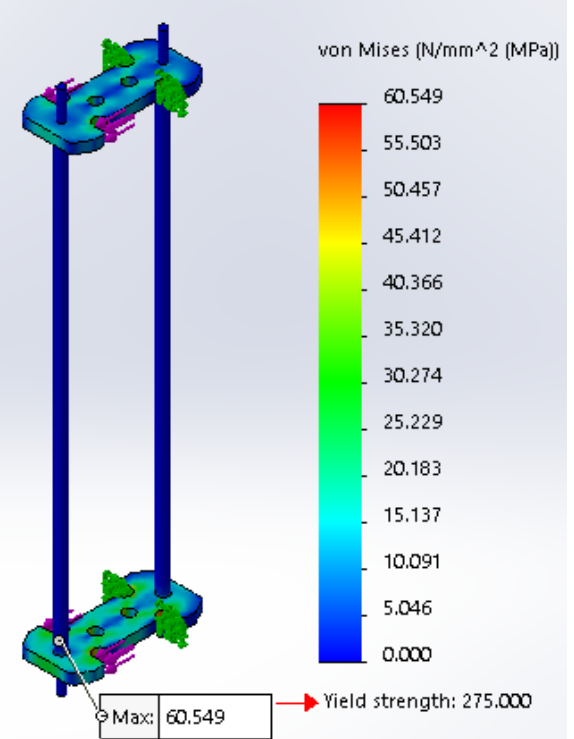

Figure 3.14 Stress Analysis Assembly Locking From Side Load 


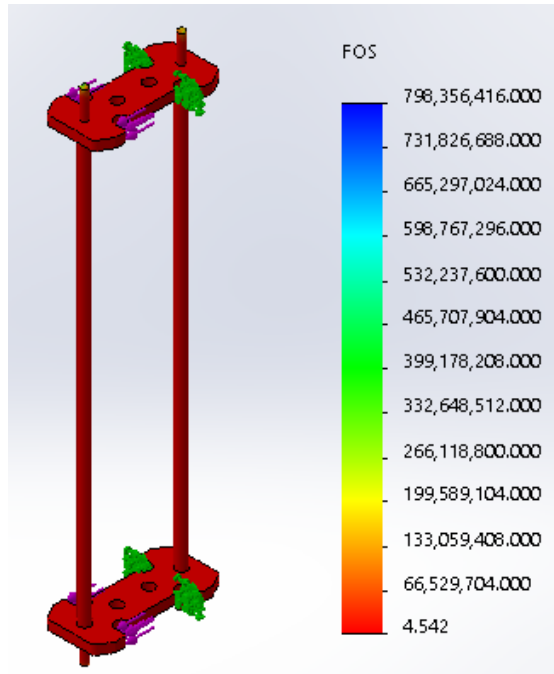

Figure 3.15 Stress Analysis Assembly Result Form Side Lock

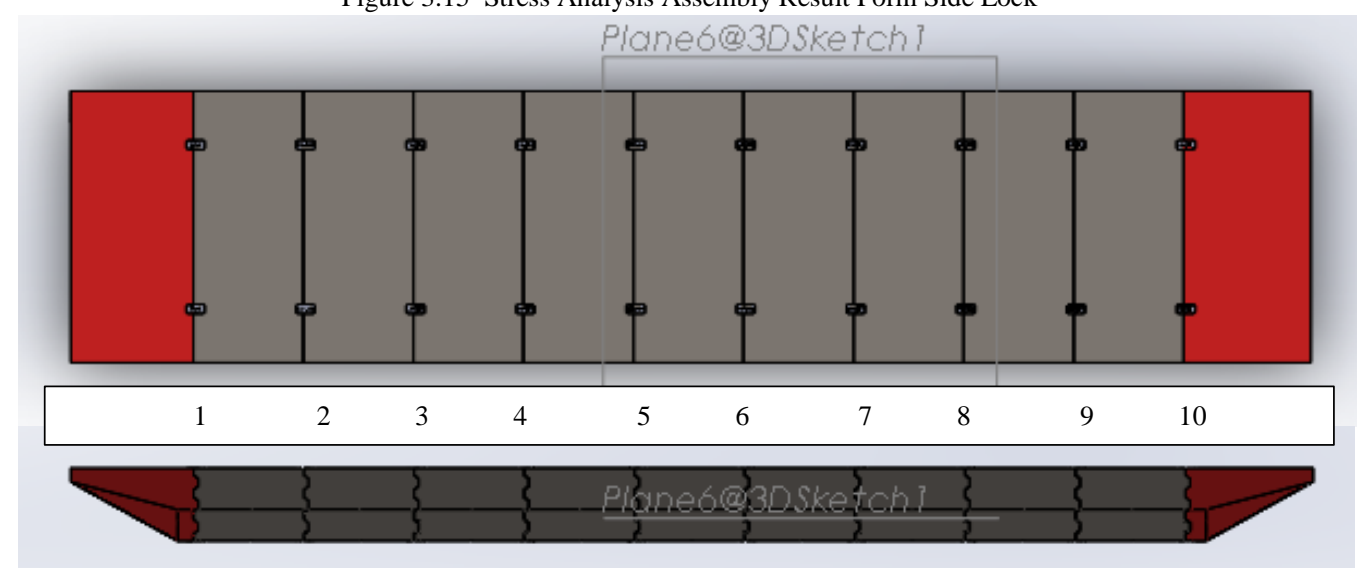

Figure 3.16 Connection Pen

Tahanan kapal

Tahanan kapal

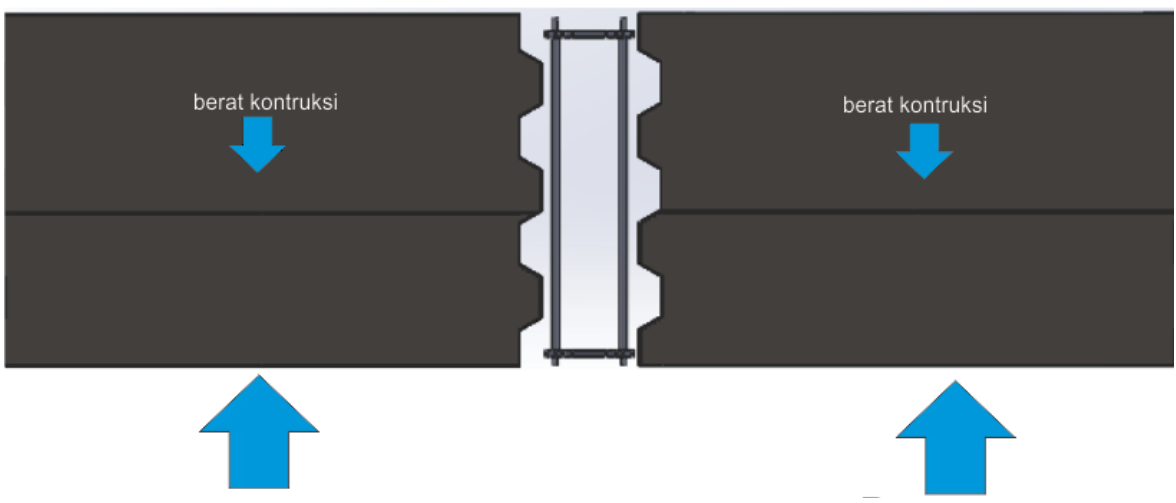

Buoyancy

Buoyancy

Figure 3.17 Distribution Load

H. Strength Analysis Of Ship Floating Conditions with Empty Cargo

- Connection Analysis No.1 

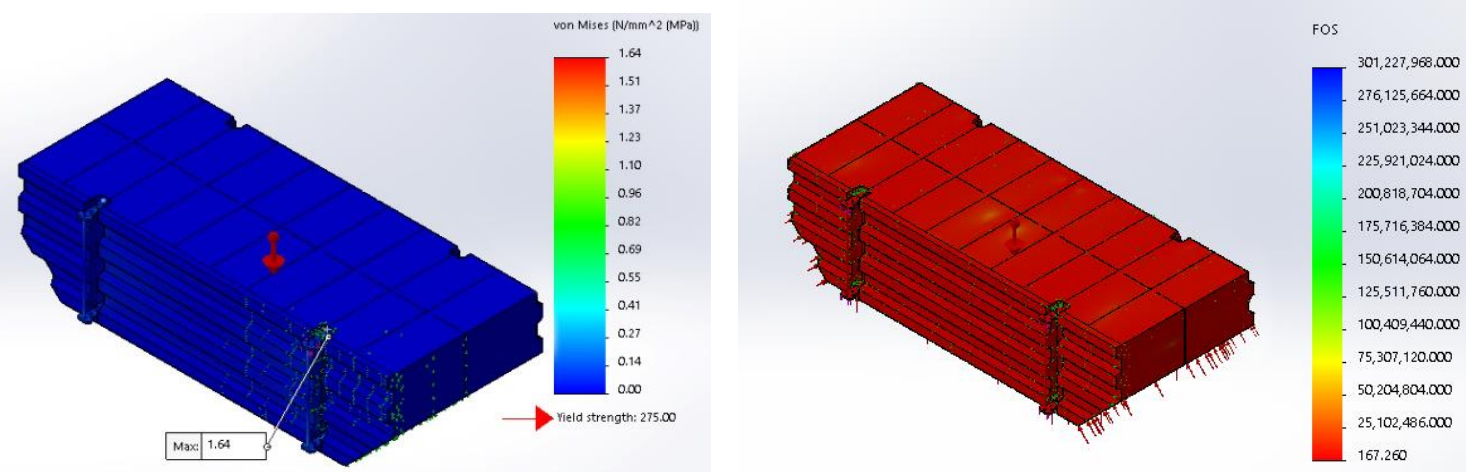

- Connection Analysis No.5

Figure 3.18 Result Connection Analysis no 1 Floating Empty Cargo

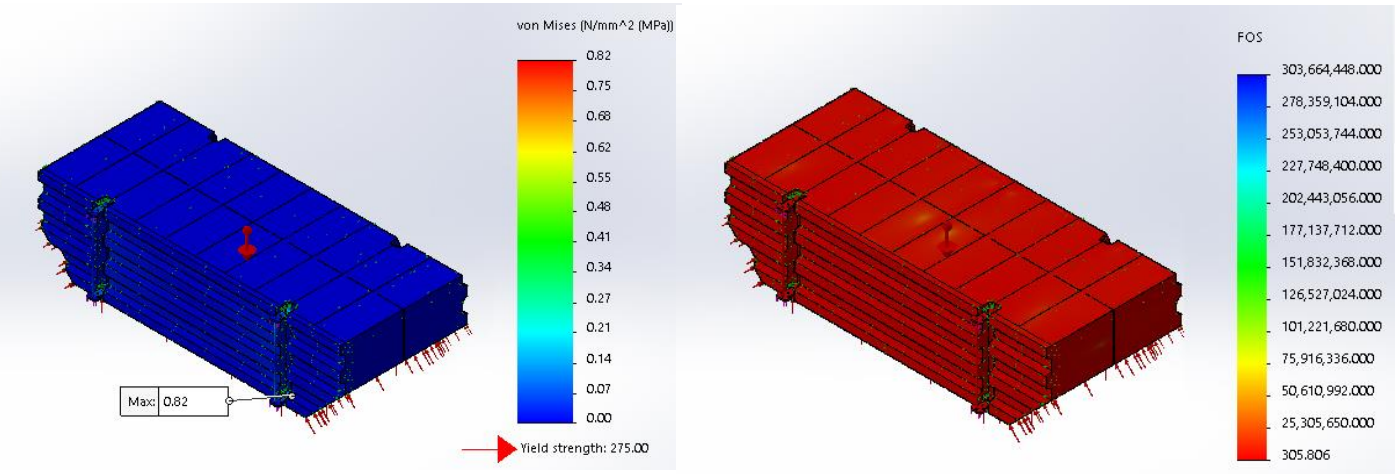

Figure 3.19 Result Connection Analysis no 5 Floating Empty Cargo

I. Strength Analysis Of Ship Floating Condition With Full Cargo

- Connection Analysis No.1
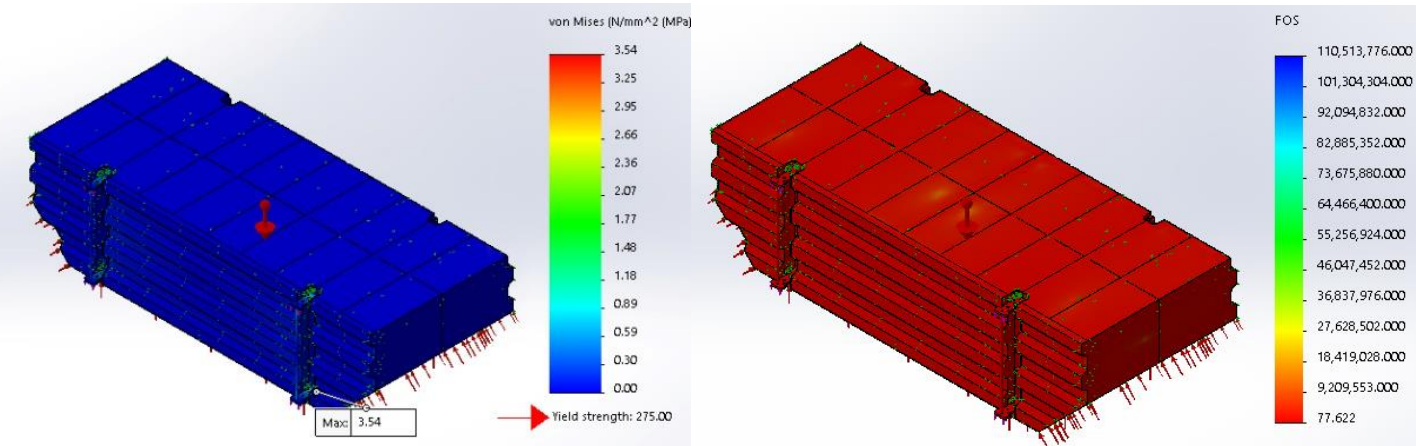

Figure 3.20 Result Connection Analysis no 1 Floating Full Cargo

- Connection Analysis No.5
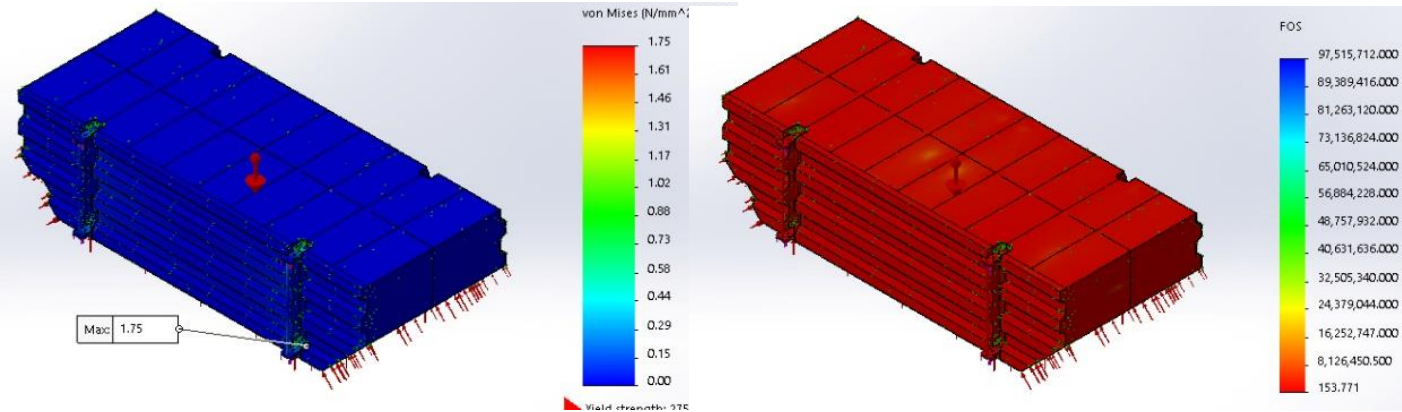

Figure 3.21 Result Connection Analysis no 5 Floating Full Cargo

J. Strength Analysis Of Ship Sailing Condition With Empety Cargo

- Connection Analysis No.1 

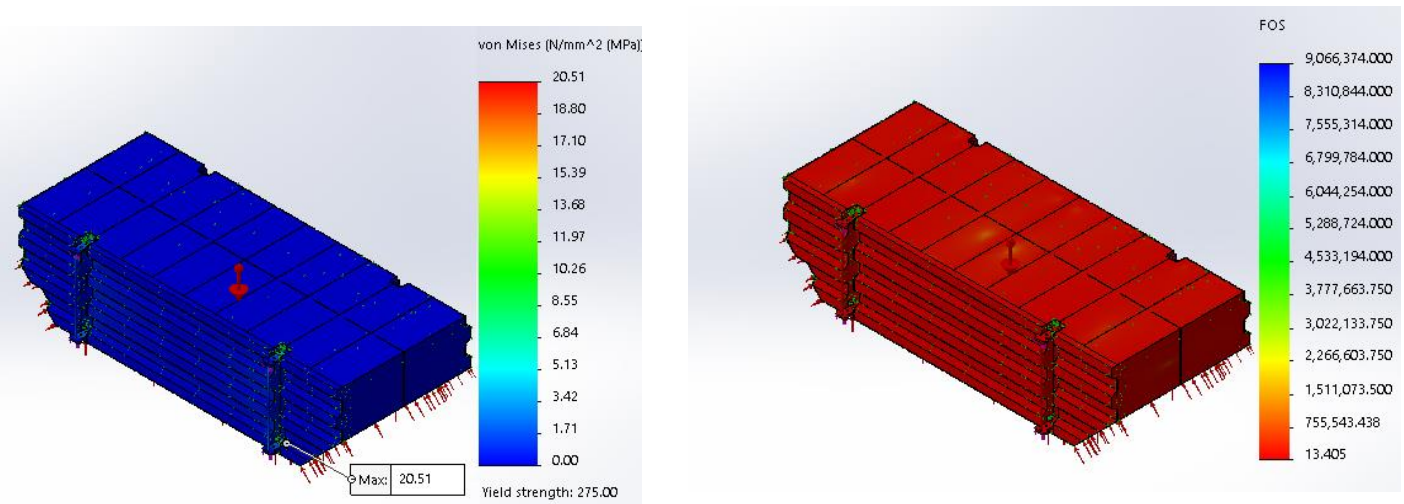

Figure 3.22 Result Connection Analysis no 1Sailing Empty Cargo

- Connection Analysis No.5
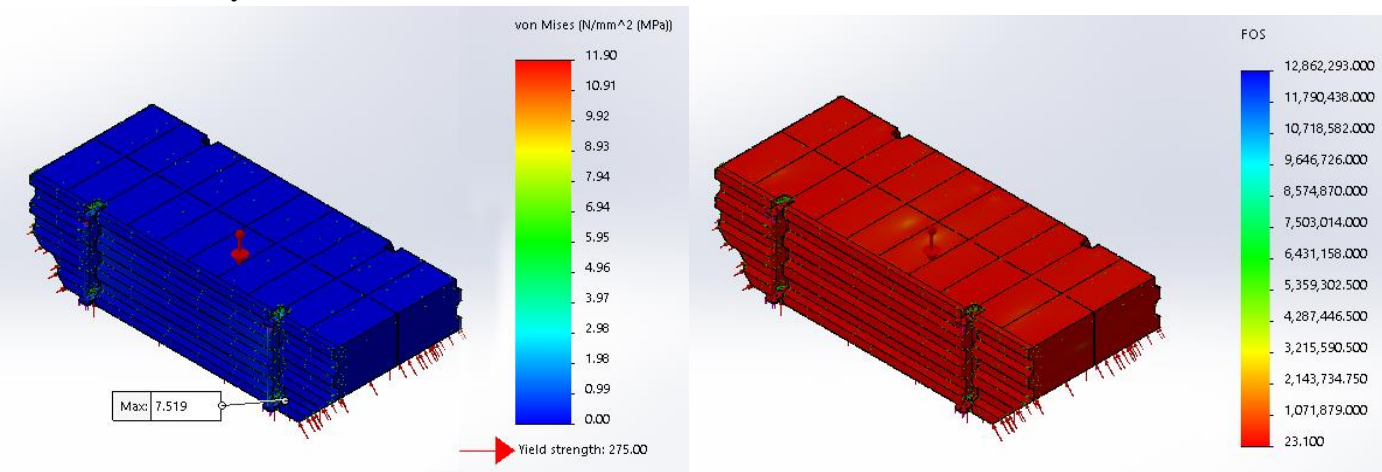

Figure 3.23 Result Connection Analysis no 5 Sailing Empety Cargo

K. Strength Analysis Of Ship Sailing Condition With Full Cargo

- Connection Analysis No.1
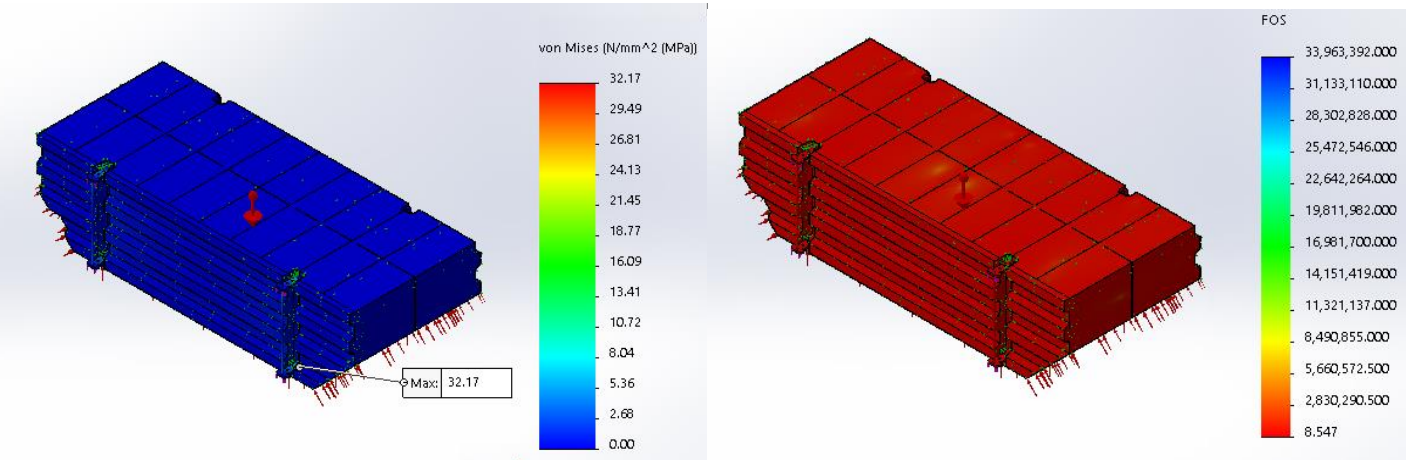

- Connection Analysis No.5

Figure 3.24 Result Connection Analysis no 1 Sailing Full Cargo
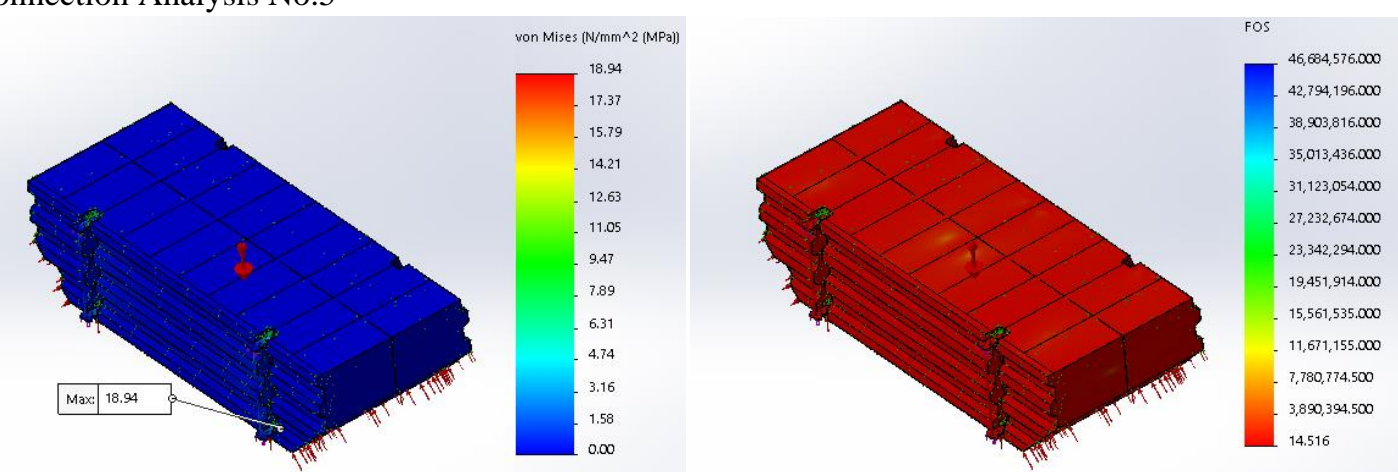

Figure 3.25 Result Connection Analysis no 5 Sailing Full Cargo

\section{REFFERENCES}

[1]

Sembakung- Nunukan. Surabaya. Teknik Perkapalan.
[2] Watson, David G.M . 1998 . Practical ship Design,Volume I . Oxford, UK : Elsevier Science Ltd. 